\title{
Accounting Treatment for Financing Impairment on Sharia Banks in Indonesia
}

\author{
Mahfisyah Putri Isa, Dwi Martani* \\ Magister of Accounting, Universitas Indonesia, Jakarta, Indonesia \\ *Corresponding author. Email: dwimartani@yahoo.com
}

\begin{abstract}
This research analyzes the accounting and calculation methods used in performing impairment on financing and aims to determine the accounting treatment used and the amount of impairment for each financing activities. The method used in this research is descriptive analysis. Data have been obtained through document analysis and observation. The results show that the PSAK 50/55 method used to perform impairment was only used in Murabahah financing, while other types of financing used the Financial Services Authority Regulation on Asset Quality Assessment of Sharia Commercial Banks and Sharia Business Units. The results of the calculations of impairment in Islamic banking showed that murabahah financing had the largest portion of financing compared to the total financing in Sharia banking in Indonesia, and the average value of impairment of murabahahh financing tends to be higher than other impairment methods others.
\end{abstract}

Keywords: Sharia Banking, Financing, Impairment

\section{INTRODUCTION}

Sharia-based financing is one of the operational activities carried out by sharia banking. Based on UU No 21 Tahun 2008, financing is done in sharia banking through several types of contracts, including murabahahh, salam, istishna, mudharabah, musyarakah, and ijarah agreements (Sekaran, 2009). The main component of the quality of assets of Islamic banks is financing that impaired and has an allowance for impairment finance (Wiroso, 2011). Therefore, impairment is very important in determining the quality of financing carried out by Islamic banks.

In conventional bank financing, accounting standards governing financing impairments are found in PSAK 55: Financial Instruments: Recognition and Recording (SAK as of January 1, 2015). The method used in impairment is the effective interest rate method. In PSAK 55, the term interest method is a method used to calculate the amortized cost of a financial asset or financial liability and a method for allocating interest income or interest expense during the relevant period (Ikatan Akuntan Indonesia, 2015). The effective interest rate is a fixed rate that discounts estimated cash payments or receipts in the future through the expected life of the future financial instrument or, when appropriate, a shorter period to obtain the net carrying amount of the financial asset or financial liability (Ikatan Akuntan Indonesia, 2015).

The use of the effective interest rate method has the advantage of being able to predict cash inflows from payments for financing that are channeled more precisely than the usual allowance method (Febriati, 2013). However, the effective interest method uses the principle of the time value of money, which is contrary to one of the characteristics of sharia transactions in the SAK Syariah KDPPLKS (Ikatan Akuntan Indonesia, 2014). Thus, the effective interest rate method contained in PSAK 55 cannot be applied in calculating Islamic financing impairments in sharia banking.

In channeling financing, almost all Islamic banks in Indonesia make allowances for such financing based on collectability. The allowance based on collectibility levels is different with impairments, so that the allowance made does not reflect the conditions of cash inflows that are more appropriate than payments for the disbursed financing. The inaccuracy of the cash flow can be seen from the adjustment of the allowances (both correction and recovery) that is significant at the beginning of each new book year. The absence of accounting standards and/or accounting guidelines governing Islamic financing impairments means that the 
allowance based on collectability is the method of impairment that the management has done.

\section{LITERATURE REVIEW}

\subsection{Sharia Banking}

Banks that carry out their activities based on sharia principles are also called sharia banks. In the sharia banking industry, sharia banks are categorized by three activities, namely, sharia commercial banks, sharia financing banks, and sharia business units that include institutions, processes, procedures, and activities in businesses based on sharia principles (Hanif, 2011). Sharia commercial banks are Islamic banks that carry out service activities in the form of payment traffic. Sharia Financing Bank is a sharia bank that does not carry out service activities in the form of payment traffic. Sharia business unit is a unit that is part of the bank's head officeConventional Banks domiciled abroad, that carry out activities based on sharia principles.

One of the basic differences between and Islamic banks is the system used to generate profits (Hanif, 2011). Conventional banks apply a system of interest to generate profits, while Islamic banks implement a profit-sharing system in generating profits. In the course of financing, the basic references for Islamic banks in preparing financial statements are the Statement of Financial Accounting Standards (IAS) and the Indonesian Sharia Banking Accounting Guidelines 2013 (PAPSI, 2013).

\subsection{Banking Risk}

In order to implement the precautionary principle, banks require certain steps be taken in order to maintain high-quality financing through effective risk management by developing policies and guidelines to apply as regulations.

There are ten risks in sharia banking: risk in credit, markets, liquidity, operations, legal, strategic, compliance, reputation, rate of return, and equity investment (Republik Indonesia, 2008).

\subsection{Risk Management}

The main objective of credit risk management is to minimize risks that can cause losses to the bank. In general, implementing risk management for credit risk includes at least the active supervision of the directors and board of commissioners, risk management policies and procedures, and risk limit determination, as well as risk identification, measurement, the risk control process and monitoring, a credit risk in management information system, and an internal control system.

\subsection{Financing Quality Assessment}

Based on the provisions of the regulator banks must determine the quality of the financing. An assessment of the quality of the financing is based on factors like the prospects of the business, customer performance, and the ability to pay.

The bank evaluates the quality of financing by analyzing the assessment factors mentioned above and by considering other assessment components based on the provisions of the authority. Based on the bank's assessment, the financing quality is set as current, special mention, substandard, doubtful, and loss.

Among the ways that banks must manage risk are maintaining asset quality and calculating the allowance for asset losses. Banks are required to provide allowances for asset losses for financing in the form of general provisions and special provisions.

\subsection{Provision for Impairment Losses}

The appropriateness of PSAK 50, 55, and 60 impairment is a condition where there is objective evidence of an adverse impact on asset value as a result of one or more events that occurred after the initial recognition of a financial asset. These adverse events have an impact on the estimated future cash flows.

Banks must conduct an assessment to indicate asset impairment. If it is proven that the financing is impaired, the bank must form a reserve for the financing by forming Cadangan Kerugian Penurunan Nilai (CKPN) or provisions as Individual and Collective.

In determining collective impairments, banks use a statistical model analysis with the following formula:

$$
\begin{aligned}
& \text { Rate of Loss = PD X LGD X LIP } \\
& \text { PD = Prrobability of Default } \\
& \text { LGD = Loss Given Default } \\
& \text { LIP = Loss Identification Period }
\end{aligned}
$$

\section{RESEARCH METHODOLOGY}

This research uses a qualitative and quantitative descriptive research approach. Qualitative research is research that aims to understand the phenomena experienced by the subject of research, which can be in the form of behavior, perception, motivation, actions, and other reactions and explained descriptively in a specific natural context and by utilizing various natural methods (Moleong, 2011). The type of qualitative research used is case study research. The reason for using case studies as a research method is because this research is research on one group, namely, sharia banks in Indonesia, that is an in-depth, comprehensive effort to find out the cause of the problem. Quantitative research 
is research that aims to measure aspects of social phenomena using objective methods.

The scope of the analysis in this research is financing in sharia banking in Indonesia, namely, the impairment financing method applied. This research will provide information about the financing activities so that they can overcome the problems that may occur.

The unit of analysis is the data collected at the time of data analysis (Sekaran, 2009). The unit of analysis in this research is sharia banks in Indonesia. Data is obtained from Sharia Banking financing impairments in Indonesia, which are contained in the Financial Reports and related Islamic Bank Annual Reports.

The procedure of data collection carried out in this research begins with conducting preliminary research and after that analyzing the documents related to financing in Islamic banks, especially the method of financing impairment.

This research will use secondary data, which is data obtained by researchers through intermediary media. In this case, the secondary data is in the form of company documents and literature, regulations, and other documents relating to the recording of Islamic financing impairments.

Analysis of the data in this research consists of data reduction, data presentation, and drawing conclusions.

\section{FINDINGS AND ANALYSIS}

Based on the results, there are several problems related to staff assignments on audit planning.

\subsection{Overview of Sharia Financing in Sharia Banking in Indonesia}

Islamic finance in Indonesia consists of Murabahahmurabahahh financing, istishna financing, salam financing, mudharabah financing, musyarakah financing, ijarah financing, and qardh financing. Each bank carries out risk management on financing, one part of which is the provision of a reserve fund for a decrease in the value of each financing transaction. The method used in the preparation of reserves for these assets consists of two methods, namely, the PSAK 50/55 method, also called the Allowance for Impairment Losses method, and the method regulated in POJK No. 16/POJK.03/2014, also called the Collectability method.

There are 12 Islamic banks in Indonesia, but not all banks carry out all types of financing. Total sharia financing in all sharia banks in Indonesia was IDR 163 trillion in 2016 and IDR 175 trillion in 2017. Murabahahh financing is carried out by all sharia banks in Indonesia. The largest amount of financing is carried out by PT Bank Syariah Mandiri, PT Bank Muamalat
Indonesia, and PT BNI Sharia. The average amount financed by the three Murabahahmurabahahh banks was almost Rp 23 trillion in 2016, and Rp 24 trillion in 2017.

\subsection{Analysis of Methods for Impairment of Financing in Sharia Banking in Indonesia}

Based on the explanation above, it could be concluded that all Islamic banks in Indonesia apply PSAK 50/55 in reserving a decrease in the value of murabahahh financing. However, there are several banks that do not explicitly confirm that the bank has provided an allowance for impairment losses using PSAK 50/55, namely, PT Bank Syariah Bukopin, PT BCA Syariah, and PT Maybank Syariah Indonesia. These three banks stated in the Notes to the Financial Report that "impairment is based on the initial effective interest rate used to discount the future cash flows for the asset" and this statement is in accordance with the method of reserve for impairment losses applied in PSAK 50/55. Allowance for impairment losses using PSAK 50/55 in Murabahahmurabahahh financing is in accordance with the rules for the provision of loss for murabahahh value listed in PSAK 102. Financing other than murabahahh uses the POJK No.16/POJK.03/2014.

\section{CONCLUSION}

Based on the findings and analysis, a few conclusions can be drawn.

1. Islamic finance in Indonesia consists of Murabahahmurabahahh financing, istishna financing, salam financing, mudharabah financing, musyarakah financing, ijarah financing, and qardh financing. However, not all Islamic banks in Indonesia carry out all the Islamic financing activities. However, in the case of murabahahh financing, all banks carry out such financing, and there is even one bank that channels almost all its funds for murabahahh financing, namely Bank Muamalat (almost 100\%). A lot of the financing that is carried out by almost all sharia banks in Indonesia is musyarakah financing. Musyarakah financing is carried out by all banks except PT Bank Tabungan Pensiunan Nasional. The third most widely funded type of financing by Islamic banks in Indonesia is mudharabah and qardh financing. The financing that is not carried out by sharia banks in Indonesia is istishna financing and ijarah financing, which are only carried out in four to five banks.

2. There are two methods for making an allowance for impairment losses, namely using PSAK 50/55, which has a time value of money factor in it and uses POJK No. 16 / POJK.03 / 2014. In this regulation, reserves are made by looking at the level of collectibles of the financing. The results of 
the research on the method used for each financing contract in all Islamic banks in Indonesia was found that the reserve for impairment losses using PSAK $50 / 55$ was only applied to the murabahahh contract. This is due to the large portion of murabahahh financing in a bank when compared to the total financing made by the bank. PSAK 50/55 can describe cash flow, which is more appropriate because it includes the time value of money factor in its calculations. Whereas the allowance for impairment losses uses the POJK No. 16/POJK.03/2014 in all financing other than murabahahh, namely istishna financing, mudharabah financing, musyarakah financing, ijarah financing, and qardh financing.

3. The results of the research on all financing carried out by Islamic banks in Indonesia showed the largest financing channel was for Murabahahh financing with a share of $60.67 \%$ in 2016 and $60.11 \%$ in 2017 . Next was musyarakah financing with a share of $36.85 \%$ in the year 2016 and $38.02 \%$ in 2017 , and the third largest financing channel was mudharabah financing with a share of $5.56 \%$ in 2016 and $4.30 \%$ in 2017 . The results of the research on the value of reserves of impairment losses by Islamic banks throughout Indonesia found that the average reserve for impairment losses for two years used the PSAK 50/55 method, which was equal to $5.81 \%$, which was $6.54 \%$ in 2016 and then the natural reserves improved in 2017 at $5.08 \%$. Whereas if the POJK rule No. 16/POJK.03/2014 is used the average reserve for financing is $3.67 \%$.

This research is limited in the scope of data obtained. The researcher obtained data only from the analysis of documents, namely financial report documents and annual reports of all sharia banking in Indonesia. This research is limited to the value of impairments found in the Financial Statements and
Annual Reports of each bank. Thus, the value of impairment for each financing transaction is not totaled.

Then the suggestion from the results of the research carried out include the following:

1. In order for Islamic banks in Indonesia to maximize risk management related to Islamic finance so that the provision of funds can be more effective.

2. To the Sharia Accounting Standards Board (DSAS) Indonesia in order to develop a policy of decreasing impairment losses for Islamic finance in accordance with the rules of Islamic law.

\section{REFERENCES}

[1] Febriati, E. C. (2013). "Analisis Penerapan PSAK 55 atas Cadangan Kerugian Penurunan Nilai". Jurnal EMBA 1 (2013) 207-217.

[2] Hanif, M. (2011) "Differences and Similarities in Islamic and Conventional Banking”.

[3] Ikatan Akuntan Indonesia, (2014). "Standar Akuntansi Keuangan Syariah, Per 1 Januari 2014”.

[4] Ikatan Akuntan Indonesia, (2015). "Standar Akuntansi Keuangan, Per 1 Januari 2015”.

[5] Moleong, L.J. (2011). Metodologi Penelitian Kualitatif. (Edisi Revisi). Bandung: PT Remaja Rosdakarya.

[6] Republik Indonesia. (2008). "Undang-Undang No. 21 Tahun 2008 tentang Perbankan Syariah”.

[7] Sekaran, U. (2009). Researh Methods For Business: Metodologi Penelitian Untuk Bisnis. (Edisi 4). Jakarta. Salemba Empat.

[8] Wiroso. (2011). Produk Perbankan Syariah. (Edisi 2). Jakarta. LPFE Usaksti. 